This happy occasion, which comes at a time when signs of a worldwide decline in respect for human dignity give serious cause for concern. is an opportunity for me to make an earnest, twofold appeal:

- I call on the Federation and the 162 National Societies to engage, to the best of their abilities, in prevention by dissemination, firmly committing themselves to a culture of non-violence, tolerance and solidarity, and

- through these same National Societies I call upon the governments of the 185 States party to the Geneva Conventions to take seriously their pledge to respect and ensure respect for international humanitarian law.

The dedication evidenced today must constantly be renewed by the whole Red Cross and Red Crescent Movement; it must unite all of us in a fresh spirit of honesty, professionalism and creativity. It is tragically pointless to be united and universal if the Movement fails to be effective. But it cannot be effective unless we know what is expected of us, what specific task is assigned to each one of us. We must know the clear division of labour between the various partners involved in humanitarian endeavour.

To be sure, the Movement must grow more united and universal day by day, but it must also become more effective! The world needs us and it must be able to count on a Movement capable of meeting the great humanitarian challenges while respecting the fundamental principles of the Red Cross and Red Crescent.

May each of us - the International Federation, the National Societies and the ICRC - rise to meet these challenges, each according to our calling and specific capacity.

Vive valeque!

\title{
ADDRESS BY THE PRESIDENT OF THE INTERNATIONAL FEDERATION OF RED CROSS AND RED CRESCENT SOCIETIES, MR MARIO VILLARROEL LANDER
}

On the threshold of the year 2000, the solution to major present-day problems and respect for the universal values on which humanitarian action is founded are interlinked. No sustainable progress in protecting human life, alleviating suffering, combating hunger and disease and promoting détente and cooperation can be achieved unless such efforts are combined with measures to safeguard human dignity.

Clearly this new awareness and this new reality, this change of purpose and energy must be fostered. The interests and values of all humanity converge in 
time of conflict, as in the ever-increasing number of disaster situations. It is possible today to adopt a new approach, based not only on moral justification and the urgency of humanitarian action, but also on the advisability of and need for such action. This is in the best interest of all mankind.

I should like to highlight, in this somewhat philosophical context, the major role played by the International Federation of Red Cross and Red Crescent Societies in bringing relief to the most vulnerable. The Federation's humanitarian work outside conflict zones is made possible only by the solidarity demonstrated by all its member National Societies. Since it was founded in 1919, the Federation has launched some 800 appeals in connection with emergencies that occurred in about 150 countries.

If in 1992 and the beginning of 1993 more than 50 international relief appeals were launched, representing approximately 305 million Swiss francs, and if the development strategy adopted for the '90s can harness the dynamic forces of the National Societies in favour of the most vulnerable, it is because of this humanitarian mobilization, the symbol of the spirit of mutual aid which prevails in the Movement. This mobilization has pride of place in our constantly changing world; its objective is to enhance brotherhood, justice and peace.

Today, as yesterday, the effectiveness of the Red Cross and Red Crescent network of solidarity depends on the support and cooperation of the States which have joined forces for humanity and undertaken to protect human life in signing the most universal of treaties: the Geneva Conventions.

Our Institution, called the International Federation of Red Cross and Red Crescent Societies since 1991, brings together 162 National Societies representing all continents and numbers some 125 million members, all guided by the same seven Fundamental Principles: humanity, impartiality, neutrality, independence, voluntary service, universality and unity.

In their capacity as auxiliaries to the public authorities in the humanitarian field and organizations subject to the laws that govern their countries, the National Societies must nevertheless maintain a degree of autonomy which enables them always to act in accordance with the Movement's Fundamental Principles. They are, moreover, the link between the Federation and their respective governments.

These National Societies are the very foundation of the Movement and its driving force. They provide the essential framework for the work of their volunteers and their staff members. The Federation acts as a permanent body for liaison, coordination and study among the National Societies and provides them with any assistance they may request. That was the aim of the five National Societies which were the co-founders of the League, today the Federation, whose universality is vital for the fulfilment of its mission. 
In conclusion, we would like this anniversary to be the occasion for a return to our origins, that is, to the convictions and principles which presided over the birth of our institution, always guided by its motto "Through Humanity to Peace".

This is not only a reminder but also an appeal to the entire human family. to all States. I am proud to make this appeal in France, the fertile country of liberty, equality and fraternity among all mankind.

The ceremony was brought to a close by Mr Douste-Blazy, who stressed the importance of the Federation's humanitarian work, especially in the areas of health and social welfare.

The delegates were later received at City Hall by Mr Jacques Chirac, Mayor of Paris, who paid tribute to the Federation and the ICRC and went on to commend the exemplary role played by the French Red Cross and its volunteers in alleviating distress in contemporary society.

*** *

Praise for the humanitarian work of the French Red Cross, founded 130 years ago, was expressed by all the speakers. In this context the Review is pleased to publish an article by Dr Jean Guillermand, who is well known to our readers, on the medical and social vocation of the French Red Cross (see pp. 287-295). 